\title{
123＼cjkstart曲がり部にスプリッタのあるダクト内部音場と流れの影響
}

\section{Effect of Mean Flow on Sound Field in a Curved Duct with Splitter}

○森 亮輔, 中部大院, $\overline{\mathbf{T}} 487-8501$, 春日井市松本町 1200

椿下庸二，中部大工， $\bar{\top} 487-8501$, 春日井市松本町1200 E-mail: tsub@isc.chubu.ac.jp

Ryosuke MORI, Dept.of Mech. Eng., Chubu University,Kasugai,Aichi 487,Japan

Yasuji TSUBAKISHITA, Dept.of Mech. Eng., Chubu University,Kasugai,Aichi 487,Japan

Key Words : Numerical Analysis , Duct Acoustics, Insertion loss, Mean Flow, Splitter

\section{1 ・まえがき}

送風機などにおいて，ダクト内で発生する騒音を低減さ せる小型の消音装置として，コーナーベーン式のものが挙 げられる。コーナーベーン式消音装置は透過側の圧力損失 が少ないため, ダクト内騒音の低減に有利である.すでに 我々は，コーナーベーン式消音装置の簡易モデルとして, 曲がり部にスプリッタが挿入されたダクトを考え, その位 置や長さを変化させた場合の透過側音場への影響に関して ダクト内部に平均流れがない場合の数値解析を行った (1). 本計算では，ダクト内部に平均流れ場がある場合について 同様のモデルに対し数值解析を行い, 特に, 中程度以下の 周波数範囲における結果について報告する.

\section{2・モテルおよび計算条件}

図 1 に示すように，直角ベンドを持つ十分長い 2 次元ダ クトを考える.曲がり部には 1 枚のスプリッタが挿入され ている．音源はダクト曲がり部より数波長手前にあり，微 小な質量の周期的なわきだし吸い込みを行うことで，平面 波を発生させる.ダクト曲がり部のスプリッタによってわ けられた音波は，スプリッタ通過後，互いに干渉する。こ の場合, スプリッタの長さや取付け位置によっては透過側 の音圧レベルが低減することが期待される.そこで本計算 で変化させるパラメータとしては， スプリッタのダクト 外壁に沿って平行にとった長さ $l$ と外壁からの距離 $a$ とす る. また, 図 1 に示すような角度 $\theta$ を導入する. ダクト幅 $h$ は $10 \mathrm{~cm}$ と固定している. 本計算では, $a / h=0.2 \sim 0.84$, $l / h=0.39 \sim 3.35\left(\theta=20^{\circ} \sim 120^{\circ}\right)$ の範囲で変化させた. なお, 音源周波数は $f=500 \sim 950 \mathrm{~Hz}$ である. また, 音 速は $c 0=341.2 \mathrm{~m}$ とする. また, 平均流れ場については, 無限上流で一様なマッハ数 $M \infty=0.2$ のダクト内部の流れ 場を数值計算して与える. 図 2 に, スプリッタの無い場合 およびある場合のダクト内におけるマッハ数分布を示す. なお, スプリッタに吸音性はなく, 各壁面では完全反射と 仮定する. 本計算で用いる音場の基礎方程式は, 微小擾 乱に基づく線形オイラー方程式であり, 陽的差分法で解か れる。計算格子数は， $1200 \times 26$ 点である.

\section{3・計算結果および考察}

図 3 には, スプリッターを挿入しない場合の音圧レベル 分布（音源周波数 $650 \mathrm{~Hz}$ ）を，平均流れの有無に対しそれ ぞれ示す。この図では, ダクト内壁側に比べ, 外壁側の音 圧レベルが高くなっている. 図 4 には, $f=650 \mathrm{~Hz}$ の場合 の挿入損失について， $\theta$ と $a / h$ をパラメータに示す.ここ で挿入損失とは, スプリッタによる透過側音圧レベル低減 量を示す. 挿入損失のピーク值を比較すると, 平均流れの ある場合の方が小さくなっている．流れの有無に関係なく，
同じ条件 $(l / h, a / h)$ において, 音圧を低減させているのが わかる.また, $l / h=1.95\left(\theta=80^{\circ}\right), a / h=0.56$ 付近で, 最も挿入損失が大きい. 図 5 は, $l / h=0.98\left(\theta=40^{\circ}\right), a$ $h=0.56$ の場合, $l / h=1.95\left(\theta=80^{\circ}\right), a / h=0.56$ の場 合，および $l / h=2.13\left(\theta=100^{\circ}\right), a / h=0.72$ における 音圧レベルおよびインテンシティの分布を表している. $\theta$ $=40^{\circ}$ の場合は，スプリッタ出口での音圧レベル変化があ まりなく，インテンシティを見ても流れの影響が出ている ものの，音圧レベル低減に影響はそれほど及ぼしていない， $\theta=80^{\circ}$ および, $100^{\circ}$ の図では, $\theta=40^{\circ}$ に比べ, スプ リッタ出口での大きな音圧レベル変化が見られる。 また, インテンシティを見ると，スプリッタ通過後大きな渦的パ ターンが見られる.この渦が大きい程, 音圧レベル低減が 大きい傾向にある.

音圧レベルの低減の要因としては，スプリッタによって 内壁側と外壁側に分けられた音波に経路差が生じスプリッ 夕通過直後の位相にずれが生じ，互いに打ち消し合い音圧 レベルが低減する．ダクト内部に流れ場があると，音速の 変化および流速の影響で位相ずれにさらに変化が生じる. 図 6 に，平均流れ場におけるスプリッタ出口音圧の時間的 変動の一例を示す. なお, $f=650 \mathrm{~Hz}$ 以外の結果について は，講演時に報告する。

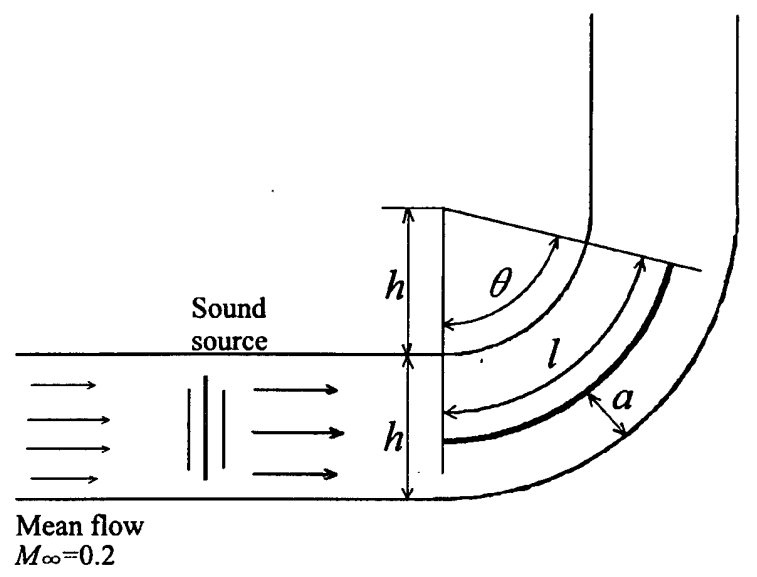

Fig. 1 Computational model

参考文献

(1) 東京工業大学精密工学研究所編:静肃工学, 開発社 (1995), 22.

（2）椿下・長崎: 第 12 回数值流体力学シンポジウム 講演論文集 （1998），113-114 

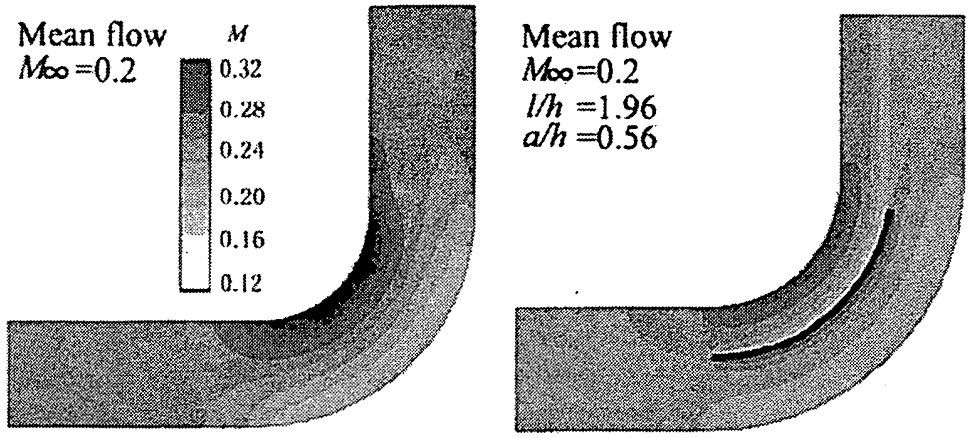

Fig.2 Mach number of mean flow
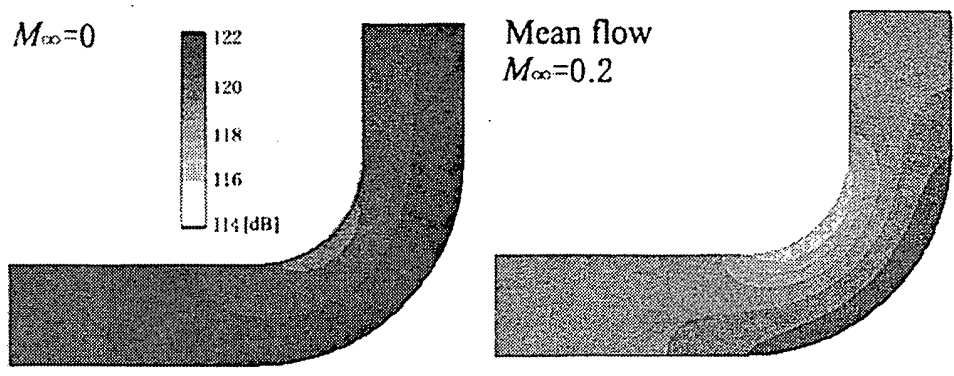

Fig.3 Sound pressure level without splitter
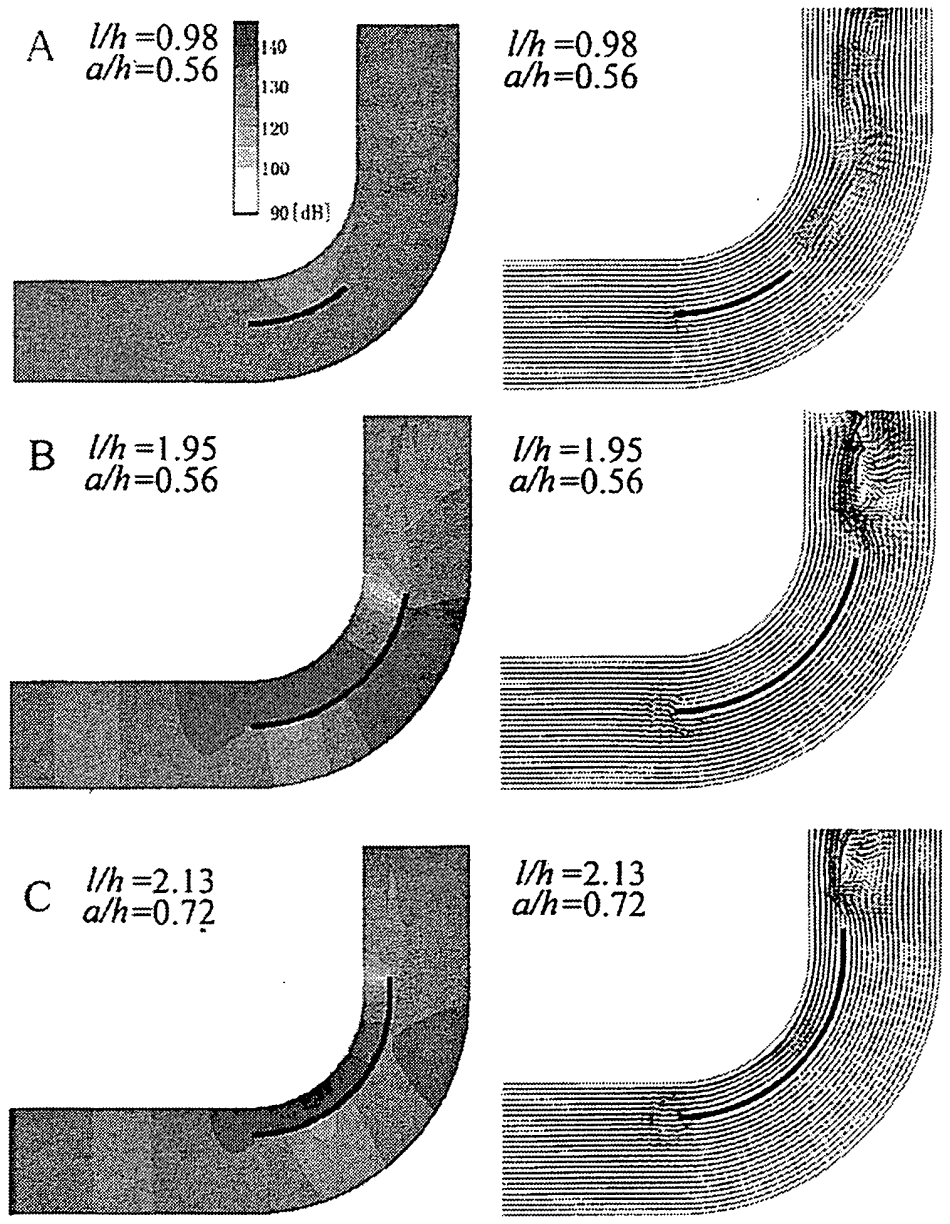
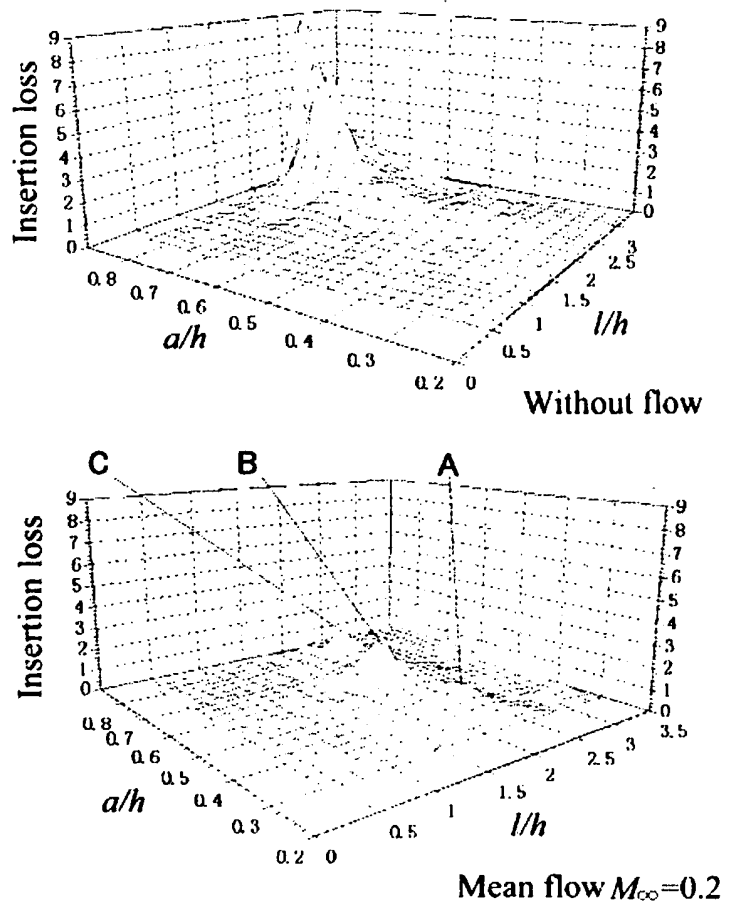

Fig.4 Effect of splitter-wall distance
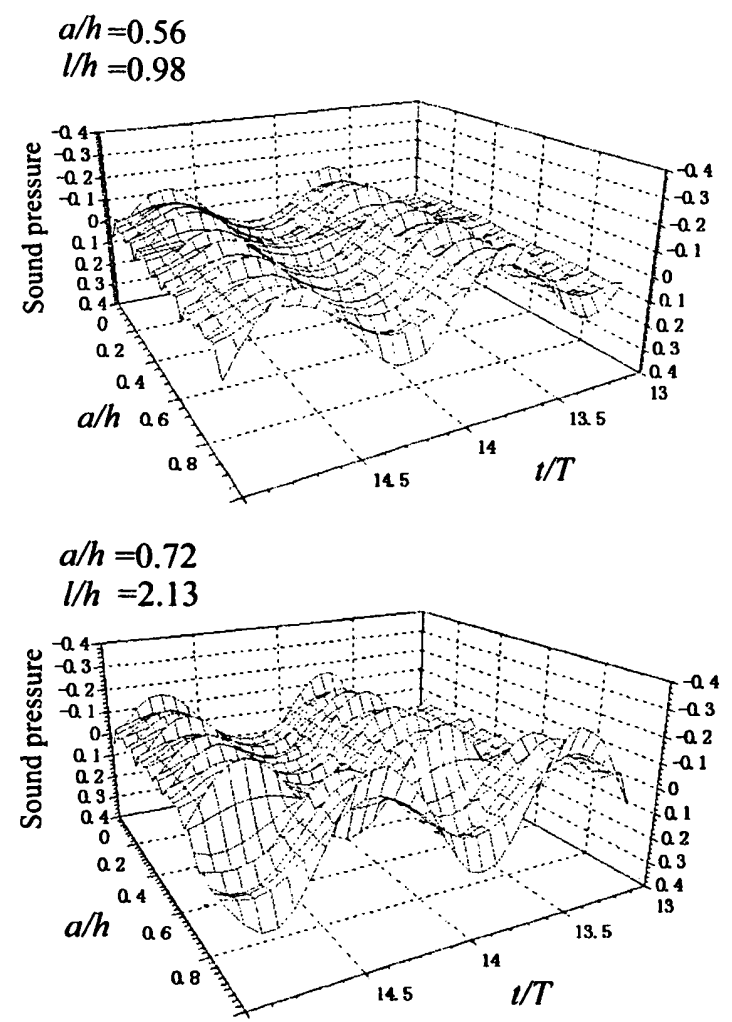

Fig.6 Time history of sound pressure and splitter length on Insertion loss

Fig.5 Distribution of SPL and Intensity for $\mathrm{f}=650 \mathrm{~Hz}, \mathrm{a} / \mathrm{h}=0$ 